\title{
The Cashless Economy and its Effects Among the Salaried Employees in Chennai City
}

\author{
S. Dhanalakshmi, K. Komalavalli, R. Hemalatha
}

\begin{abstract}
The government has implemented a major change in economic environment by demonetizing the high value currency notes of Rs.500 and Rs.1000 from 8th November 2016 and push India towards cashless future. The present study aimed to know about the awareness and acceptance of the cashless economy among the salaried employees in Chennai city. Data was directly collected from the online users and analyzed using percentages. The result of the study shows that the salaried employees are accepting and adopting cashless economy due to its comfort and transparency.
\end{abstract}

Keywords : Cashless Economy, Digital Payments, Awareness, Security.

\section{INTRODUCTION}

Digitalization leads to change in traditional payment methods, due to development of banking industries and internet services. Digital payment methods save time and helps in easy transfer of money.

Cashless economy means that people do their financial transactions without using currencies or coins. In cashless economy the money transactions are done through electronic modes like, mobile phones, computers, laptops etc. The various modes of cashless transactions used by the people are debit card, credit card, electronic fund transfer and internet banking etc. Most of the developed countries are following cashless economy, thus India started its way towards cashless economy, which will helps in transparency in financial transactions which leads to control in corruption. Now most of the people are aware about the digital payments they were adopting their payments towards online with more convenient and satisfaction.

\section{OBJECTIVES OF THE STUDY}

- To find out demographic profile of the salaried employees using digital payments

- To assess the method and amount of transactions used by employees

- To study the advantages of cashless economy

- To analyze the awareness and level of satisfaction in cashless economy

Revised Manuscript Received on December 05, 2019.

* Correspondence Author

S. Dhanalakshmi*, Assistant Professors, Department of Commerce, Sriram College of Arts \& Science, Thiruvallur, India

Dr. K. Komalavalli, Assistant Professors, Department of Commerce, Sriram College of Arts \& Science, Thiruvallur, India

Dr. R. Hemalatha, Assistant Professors, Department of Commerce, Sriram College of Arts \& Science, Thiruvallur, India

\section{METHODOLOGY}

The study was conducted among the salaried employees of both public and private sectors in Chennai city. Primary data were collected from the salaried employees by using structured questionnaire. The questionnaire was designed to collect information related to demographic profile of the online users, awareness about the cashless economy, mode of transactions, type of products and the range of purchase per month through cashless payments. Questionnaire was issued to 100 users out of which 87 were selected for the study 13 questionnaire was rejected due to incompleteness. The sampling method used for the study was Simple convenient random sampling. Collected data is analyzed by calculating simple percentages.

\section{REVIEW OF LITERATURE}

Budheswar Prasad singhraul and yogitasatishgarwal (2018) the study uses secondary data collected from various countries using digital currencies, to compare and find the challenges and opportunities of cashless economy. The result of the study shows that the cashless economy is useful for the economic growth and development and it also concludes that India has taken a right step to improve its economy.

Dominic, Saranya, and Rajani (2018) the study examines the approach of individuals towards the cashless economy. The study was conducted among fifty users comprising businessmen, government employees, students, and housewives etc. The result of the study shows that majority prefer cash transactions because of the degree of high risk associated with the digital transaction and high rate of digital illiteracy.

Rajanna K. A (2018) aimed to find the response of customers towards cashless economy in chickmangaluru, District of Karnataka. The study findings show that the customers are aware about the cashless economy and they also agree that this will be defiantly against corruption and black money. They feel that it reduces the risk of carrying cash and it will also helps to faster economic growth.

Venkateswararao Podile and P. Rajesh (2017) studied perception of the general public towards cashless transactions in India. The study reveals that public feels comfortable with cashless payments but they also feel that their privacy is not secured in online transactions. They expect some more security features from the government and the financial institutions to maintain their personal details in a safe manner.

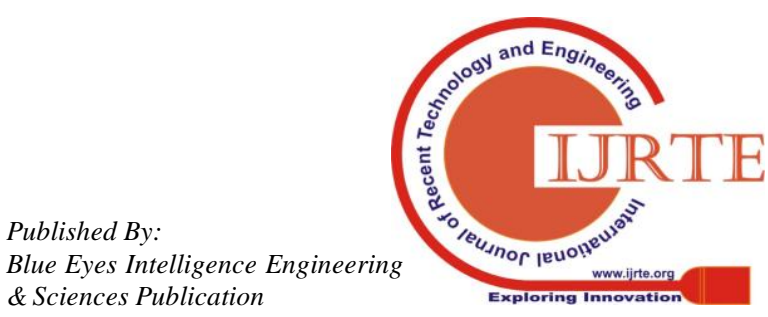




\section{MODES OF CASHLESS TRANSACTION IN INDIA}

Credit card: The credit card is the plastic card issued by the banker to the salaried employees. The card has credit worthiness limit based on their carry home pay and the banker provided limited period to repay the credit without interest.

Debit card: A debit card is a plastic prepaid card and also known as an ATM card. This is the plastic card issued by the banker to their customers to reduce the crowd in the banks and make their transaction process easy. It is secured by pin number and one time password.

Mobile payments: Using smart phones, people make their banking transaction. Now a day it is becoming more popular because most of the people using smart phones feel that they having their bank at their palms. It is more secure and convenient to carry every ware.

NEFT: National Electronic Funds Transfer is a nation-wide payment system facilitating individual to transfer any amount of money to any individual, firm or corporate who is having account in any branch or any bank in the country

\section{A. Advantages}

- Advancements in technology and increased network facilities enables improvement in all areas of all financial sectors.

- Now the cashless transfer is becoming more popular among the salaried persons because this method giving enormous benefits to them.

- Most of the salaried employees prefer online payments to pay their bills, online shopping to save their valuable time

- Online payments and transfer of funds helps them to maintain transparency in their accounting and act as an authenticate proof for their transactions

- Users of cashless economy realizes that it will helps in reducing corruption and black money in the country it will result in economic growth

- The cost of printing and transporting the currency notes to all over the country is reduced

\section{DATA ANALYSIS}

\section{Demographic Profile of the Users}

Table - 1: Age group of the users

\begin{tabular}{|c|c|c|}
\hline Age groups & No. of Users & Percentage \\
\hline upto 30 yrs & 24 & 28 \\
\hline $31-40$ yrs & 53 & 61 \\
\hline above 40 yrs & 10 & 11 \\
\hline Total & 87 & 100 \\
\hline
\end{tabular}

The above table shows that 61 per cent of the digital users belong to the age group of 31 - 40 years. The users belong to this age groups are using more cashless transactions compare to other groups.

Table - 2: Monthly Income (Rs.)

\begin{tabular}{|c|c|c|}
\hline $\begin{array}{c}\text { Monthly Income } \\
\text { (Rs.) }\end{array}$ & No. of Users & Percentage \\
\hline upto 25,000 & 21 & 24 \\
\hline $25,000-50,000$ & 42 & 48 \\
\hline
\end{tabular}

\begin{tabular}{|c|c|c|}
\hline above 50,000 & 24 & 28 \\
\hline Total & 87 & 100 \\
\hline
\end{tabular}

Above table gives the classification according to monthly income of the users. From this classification, maximum number of users (48 per cent) are in the income group of Rs.25,000 to 50,000 are using cashless transactions.

Table - 3: Gender

\begin{tabular}{|c|c|c|}
\hline Gender & No. of Users & Percentage \\
\hline Male & 56 & 64 \\
\hline Female & 31 & 36 \\
\hline Total & 87 & 100 \\
\hline
\end{tabular}

This table relates to gender classification of the users. It reveals that 64 per cent of the users are male users.

Table - 4: Education Qualification

\begin{tabular}{|c|c|c|}
\hline $\begin{array}{c}\text { Education } \\
\text { Qualification }\end{array}$ & No. of Users & Percentage \\
\hline Diploma (or) ITI & 11 & 13 \\
\hline Degree & 33 & 38 \\
\hline Professionals & 43 & 49 \\
\hline Total & 87 & 100 \\
\hline
\end{tabular}

Above table shows that educational classification of the users. From this group majority of the users (49 per cent) are professionals.

Table - 5: Marital Status

\begin{tabular}{|c|c|c|}
\hline Marital Status & No. of Users & Percentage \\
\hline Married & 49 & 56 \\
\hline Unmarried & 38 & 44 \\
\hline Total & 87 & 100 \\
\hline
\end{tabular}

This table expresses the sample frequency based on the marital status. Majority of the users (56 per cent) are married users using cashless transactions.

Table - 6: Type of Employment

\begin{tabular}{|c|c|c|}
\hline $\begin{array}{c}\text { Type of } \\
\text { Employment }\end{array}$ & No. of Users & Percentage \\
\hline Government & 45 & 52 \\
\hline Private & 42 & 48 \\
\hline Total & 87 & 100 \\
\hline
\end{tabular}

Type of employment divided into two types, namely private employees and government employees. From this type 52 per cent of the government employees are using cashless transactions.

\section{Method and Amount of Transaction Used}

Table - 7: Mode of transaction

\begin{tabular}{|c|c|c|}
\hline Mode of transaction & No. of Users & Percentage \\
\hline Debit Card & 22 & 25 \\
\hline Credit Card & 28 & 32 \\
\hline NEFT & 20 & 23 \\
\hline Mobile App. & 17 & 20 \\
\hline Total & 87 & 100 \\
\hline
\end{tabular}

This table shows that respondent's mode of using transactions at the time of cashless transactions. From this table 32 per cent of the users are using credit card followed by 25 per cent of the users are using debit card followed by 23 per cent of the users are using 
NEFT and 17 per cent of the users are using mobile app. for their cashless transactions.

\begin{tabular}{|c|c|c|c|c|}
\hline Items & $\begin{array}{c}\text { Below } \\
\mathbf{5 , 0 0 0}\end{array}$ & $\begin{array}{c}\mathbf{5 0 0 0}- \\
\mathbf{1 0 , 0 0 0}\end{array}$ & $\begin{array}{c}\text { Above } \\
\mathbf{1 0 , 0 0 0}\end{array}$ & Total \\
\hline Food & $79(91 \%)$ & $8(9 \%)$ & $0(0 \%)$ & $87(100)$ \\
\hline Groceries & $32(37 \%)$ & $41(47 \%)$ & $14(16 \%)$ & $87(100)$ \\
\hline Garments & $21(24 \%)$ & $57(66 \%)$ & $9(10 \%)$ & $87(100)$ \\
\hline Accessories & $23(26 \%)$ & $47(54 \%)$ & $17(20 \%)$ & $87(100)$ \\
\hline Electronics & $16(18 \%)$ & $42(48 \%)$ & $29(34 \%)$ & $(100)$ \\
\hline
\end{tabular}

Table - 8: Amount of Purchase (Rs.)

This table indicates that amount spend on different items at the time of cashless purchase. In food items majority of the users spend below 5,000, followed by groceries 47 per cent of the users are spent Rs. 5,000 to 10,000, followed by garments 66 per cent of the users are spend Rs. 5,000 to 10,000, followed by accessories 54 per cent of the users are spend Rs. 5,000 to 10,000 finally electronics items 48 per cent of the users are spend Rs. 5,000 to 10,000.

Table - 9: Service Payments

\begin{tabular}{|c|c|c|c|c|}
\hline Payments & Yes & \% & No & \% \\
\hline Electric Bill & 68 & 78 & 19 & 22 \\
\hline Telephone Bill & 72 & 83 & 15 & 17 \\
\hline Cash Transfer & 35 & 40 & 52 & 60 \\
\hline LIC Policy & 41 & 47 & 46 & 53 \\
\hline
\end{tabular}

From this table indicates that payments made for services like electronic bill, telephone bill, cash transfer and LIC policy of the users. Majority of the users are using cashless transfer for electronic bill, telephone bill, and LIC policy but from this study some of the users are hesitate to transfer the cash through online.

Table - 10: How often do you use (frequency)

\begin{tabular}{|c|c|c|}
\hline $\begin{array}{c}\text { Frequency of } \\
\text { usage }\end{array}$ & No. of Users & Percentage \\
\hline Daily & 28 & 32 \\
\hline Monthly & 37 & 43 \\
\hline Quarterly & 22 & 25 \\
\hline Total & 87 & 100 \\
\hline
\end{tabular}

This table indicates that frequency of using cashless transaction of the users. The usage of the online users was asked Daily, Monthly and Quarterly. Majority of the users (43 persons) are using monthly pattern of their cashless transaction.

Table - 11: Time of use

\begin{tabular}{|c|c|c|}
\hline Time of use & No. of Users & Percentage \\
\hline Regular & 59 & 68 \\
\hline Occasions & 28 & 32 \\
\hline Total & 87 & 100 \\
\hline
\end{tabular}

From this table shows that maximum of the users $(68 \%)$ use cashless transactions for regular use.

Table - 12: Level of Satisfaction

\begin{tabular}{|c|c|c|c|c|c|}
\hline Contents & $\begin{array}{c}\text { Highly } \\
\text { Satisfied }\end{array}$ & Satisfied & Neutral & Dissatisfied & $\begin{array}{c}\text { Highly } \\
\text { Dissatisfi } \\
\text { ed }\end{array}$ \\
\hline
\end{tabular}

\begin{tabular}{|c|c|c|c|c|c|}
\hline Security & $22(25 \%)$ & $28(32 \%)$ & $20(23 \%)$ & $11(13 \%)$ & $6(7 \%)$ \\
\hline Gateway & $27(31 \%)$ & $24(28 \%)$ & $18(21 \%)$ & $9(10 \%)$ & $9(10 \%)$ \\
\hline Easy Access & $35(40 \%)$ & $27(31 \%)$ & $12(14 \%)$ & $8(9 \%)$ & $5(6 \%)$ \\
\hline $\begin{array}{c}\text { Understandabl } \\
\text { e }\end{array}$ & $20(23 \%)$ & $26(30 \%)$ & $32(37 \%)$ & $6(7 \%)$ & $3(3 \%)$ \\
\hline $\begin{array}{c}\text { Growth of } \\
\text { mobile } \\
\text { payments }\end{array}$ & $34(39 \%)$ & $22(25 \%)$ & $17(20 \%)$ & $10(11 \%)$ & $4(5 \%)$ \\
\hline $\begin{array}{c}\text { Internet } \\
\text { Connections }\end{array}$ & $18(21 \%)$ & $19(22 \%)$ & $41(46 \%)$ & $4(5 \%)$ & $5(6 \%)$ \\
\hline $\begin{array}{c}\text { Service } \\
\text { Charges }\end{array}$ & $12(14 \%)$ & $15(17 \%)$ & $11(13 \%)$ & $31(36 \%)$ & $18(20 \%)$ \\
\hline $\begin{array}{c}\text { Taxes (GST } \\
\text { etc.) }\end{array}$ & $9(10 \%)$ & $6(7 \%)$ & $17(20 \%)$ & $19(22 \%)$ & $36(41 \%)$ \\
\hline
\end{tabular}

Consumer satisfaction in cashless transaction is essentially an important factor. Satisfaction arises only when services meet the expectation of the users. Services provided by particular website as satisfied users are likely to be making repetitive transaction in future. In this part, the satisfactions of the users are asked eight contents using five point scales. The content is security, gateway, and easy access, understandable, growth of mobile payments, internet connections, service charges and taxes.

From this content satisfactory regarding security most of the users $(57 \%)$ are satisfied and highly satisfied. Secondly, gateway gives more satisfaction as $59 \%$ of the users are satisfied and highly satisfied, followed by easy access $71 \%$ of the users are satisfied and highly satisfied. And understandability $53 \%$ of the users are in the category of satisfied and highly satisfied, next growth of mobile payments $64 \%$ were opined that satisfied and highly satisfied. Internet connections are at the lowest rate $46 \%$ only feel in the category of satisfied and dissatisfied followed by service charges also in the same category of $46 \%$ are dissatisfied and highly dissatisfied. At last the regarding the taxes $53 \%$ were falls under the dissatisfied and highly dissatisfied ones.

Table - 13: Awareness

\begin{tabular}{|l|c|c|c|}
\hline \multicolumn{1}{|c|}{ Statements } & Agree & Neutral & Disagree \\
\hline $\begin{array}{l}\text { Are you aware of digital India } \\
\text { Project? }\end{array}$ & $53(61 \%)$ & $24(28 \%)$ & $10(11 \%)$ \\
\hline Do you feel Convenience? & $52(60 \%)$ & $30(34 \%)$ & $5(6 \%)$ \\
\hline If it is helps in Prompt settlement? & $57(66 \%)$ & $5(6 \%)$ & $25(28 \%)$ \\
\hline $\begin{array}{l}\text { Is there Transparency in } \\
\text { transactions? }\end{array}$ & $68(78 \%)$ & $7(8 \%)$ & $12(14 \%)$ \\
\hline $\begin{array}{l}\text { Do you think making India } \\
\text { Cashless will uplift the Standard of } \\
\text { living }\end{array}$ & $37(43 \%)$ & $23(26 \%)$ & $27(31 \%)$ \\
\hline $\begin{array}{l}\text { Whether it reduces the risk? } \\
\text { Is it helpful to control the } \\
\text { corruption? }\end{array}$ & $62(71 \%)$ & $14(16 \%)$ & $11(13 \%)$ \\
\hline $\begin{array}{l}\text { After digitalization which are all } \\
\text { become more convenient to you as } \\
\text { compared to current services } \\
\text { Beservation }\end{array}$ & $\begin{array}{l}41(82 \%) \\
\text { Education }\end{array}$ & $\begin{array}{c}5(6 \%) \\
17(20 \%)\end{array}$ & $\begin{array}{l}11(12 \%) \\
15(17 \%)\end{array}$ \\
\hline
\end{tabular}

The above table shows the awareness among the users about the cashless economy and the benefits observed by them. The opinion of the users show that in the cashless economy there are transparency in 
transactions, they really feel that it will be helpful in controlling corruption.
Most of the salaried employees' (82\%) in Chennai city are using cashless transaction for their banking transactions.

Table - 14: Advantages

\begin{tabular}{|l|c|c|c|c|}
\hline \multicolumn{1}{|c|}{ Contents } & $\begin{array}{c}\text { Highly } \\
\text { Satisfied }\end{array}$ & Satisfied & Neutral & Dissatisfied \\
Dissatisfied
\end{tabular}

The above table shows the advantages of the cashless economy. The opinion of the users shows highly satisfied for the advantages. The users realize that it will breaking down the traditional barriers and adoption of cashless policy will definitely bring economic stabilization in future.

\section{CONCLUSION}

The study was conducted among the salaried employees in Chennai city using cashless transactions. The study concludes that the most of the married male employees under the age group of 31 to 40 years are using cashless method for their payments. Many of the government employees earning 25000 to 50000 as their monthly income, using credit card for their purchase of food items, garments and accessories through online method. The salaried employees use online transfer for their monthly payments and regular payments. The study also concludes that the salaried employees are aware about the use of online shopping and online transfer they feel that it is very easy, convenient and safe for them. Growth of mobile phone users, improved technology, uninterrupted internet connections, security and transparency helps in increasing online shoppers which leads the economy to cashless which will helps the government in reducing corruption and black money. The salaried employees realize that this method will improve in economic development in future.

\section{REFERENCES}

1. Asim Husain - Synopsis submitted to the doctoral thesis "cashless transaction system: A study of Paradigm shift in Indian consumer behaviour" Dayalbagh Educational Institute U.P. India

2. Budheswar Prasad singhraul and yogitasatishgarwal (2018) "Cashless economy - challenges and opportunities in India," Pacific Business Review International volume 10, Issue 9, March.

3. Dominic, Saranya, and Rajani (2018) "A study on transformation in behaviour of individual towards cashless economy" International Journal of Pure and Applied Mathematics Special Issue, Volume 118 No. 182018 , 1365-1372.

4. Dr. K.A. Rajanna (2018) "Perception and awareness of customer towards cashless transaction; A case study" International Journal of Application or Innovation in Engineering and Management", Volume 7, Issue 3.

5. Dr. VenkateswararaoPodile and P. Rajesh (2017) "Public Perception on Cashless Transactions in India", Asian Journal of Research in Banking and Finance Vol. 7, No. 7, July 2017, pp. 63-77.

\section{AUTHORS PROFILE}

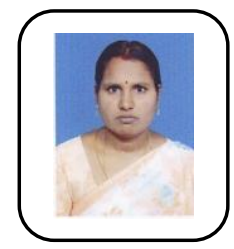

S. Dhanalakshmi is currently working as a Assistant Professor in Department of Commerce, Sri Ram College of Arts and Science, Veppampattu, Thiruvallur District having Academic Qualifications of M.Com., M.Phil., PGDCA, and passed TNSET-2016 with strong Academic Record with the service of 7 years in Teaching.

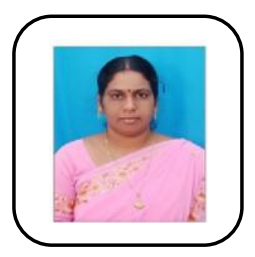

Published 10 Articles in various National and International Publications and also attended various Seminars, Workshops and Conferences of National and International to enhance the knowledge and skill.

Dr. K. Komalavalli is currently working as a Assistant Professor in Department of Commerce (Computer Applications), Sri Ram College of Arts and Science, Veppampattu, Thiruvallur Districthaving Academic Qualification of M.Com., M.Phil., Ph.D. and alsopassed NET 2012 with strong Academic Record with the service of 10 years in Teaching. Published 12 Articles in various National and International Publications and also attended various Seminars, Workshops and Conferences of National and International to enhance the knowledge and skill.

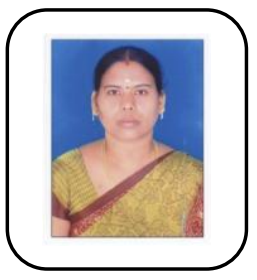

Dr. R. Hemalatha is currently working as a Assistant Professor in Department of Commerce (Corporate Secretaryship), Sri Ram College of Arts and Science, Veppampattu, Thiruvallur District having Academic Qualification of M.Com., M.Phil., Ph.D. with good Academic Record along with the service of 6 years in Teaching. Published 4 Articles in various National and International Publications and also attended various Seminars, Workshops and Conferences of National and International to enhance the knowledge and skill. 